\title{
Indeks Kepuasan Pasien terhadap Pelaksanaan Discharge Planning oleh Perawat di Ruang Rawat Inap Rumah Sakit
}

\author{
Asmuji ${ }^{1}$, Faridah ${ }^{2}$ \\ ${ }^{1}$ Fakultas Ilmu Kesehatan Universitas Muhammadiyah Jember, Jl. Karimata No. \\ 49 Sumbersari, Kabupaten Jember, Jawa Timur \\ ${ }^{2}$ Sekolah Tinggi Ilmu Kesehatan Hang Tuah Surabaya, Jl. Gadung No.1, Jagir, \\ Kecamatan Wonokromo, Kota Surabaya, Jawa Timur \\ E-mail : asmuji@unmuhjember.ac.id
}

$\begin{array}{ll}\text { Diterima tanggal } & : \text { 06 Maret } 2020 \\ \text { Direvisi tanggal } & : \text { 01 April 2020 } \\ \text { Dipublikasikan tanggal } & : \text { 11 Juni } 2020\end{array}$

\begin{abstract}
Abstrak
Latar Belakang dan Tujuan: Kepuasan pasien merupakan cermin kualitas pelayanan kesehatan yang mereka terima. Pelayanan penting yang dapat menjadi faktor penentu kepuasan pasien adalah pelayanan persiapan pemulangan (discharge planning). Discharge planning merupakan kegiatan yang dilakukan oleh tenaga kesehatan guna menyiapkan pasien agar mampu melakukan tindakan mandiri pada waktu sudah keluar rumah sakit. Tujuan penelitian ini mengidentifikasi indeks kepuasan pasien terhadap pelaksanaan discharge planning oleh perawat
\end{abstract}

Tujuan: Penelitian ini merupakan penelitian cross sectional yang dilakukan di ruang rawat inap kelas I, II, dan III dua rumah sakit di Kabupaten Jember dengan sampel sebanyak 60 responden diambil secara purposive sampling. Instrumen pengumpulan data menggunakan kuesioner.

Hasil: Rata-rata nilai harapan pada rumah sakit I adalah 3,6690 dengan rata-rata nilai kenyataan 3,0130. Rata-rata nilai harapan pada rumah sakit II adalah 3,5510 dengan rata-rata nilai kenyataan 2,9730. Indeks kepuasan pasien di rumah sakit I antara harapan dan kenyataan terdapat selisih 0,656 dan di rumah sakit II selisihnya 0,578. Hasil uji statistik ( $t$-test) menunjukkan adanya perbedaan rata-rata nilai harapan dan kenyataan, baik di rumah sakit I ( $p$ value $=0,004 ; \alpha=$ $0,05$ ) maupun di rumah sakit II ( $p$ value $=0,016 ; \alpha .=0,05)$.

Simpulan dan Implikasi: Pelaksanaan discharge planning masih belum menjadi budaya yang mengakar pada diri tenaga kesehatan termasuk perawat, sehingga pelaksanaannya belum maksimal dan belum dapat memberikan rasa puas kepada pasien sebagai penerima layanan. Dengan demikian rumah sakit wajib menetapkan kebijakan yang mengatur tentang discharge planning.

Kata kunci: Discharge planning; Kepuasan pasien, Rawat inap

Sitasi: Asmuji \& Faridah. (2020). Indeks kepuasan pasien terhadap pelaksanaan discharge planning oleh perawat di ruang rawat inap rumah sakit. The Indonesian Journal of Health Science. 12(1), 26-33

Copyright: (c) 2020 Asmuji et al. This is an open-access article distributed under the terms of the Creative Commons Attribution License, which permits unrestricted use, distribution, and reproduction in any medium, provided the original author and source are credited.

Diterbitkan Oleh: Universitas Muhammadiyah Jember

ISSN (Print): 2087-5053

ISSN (Online): 2476-9614 


\begin{abstract}
Patients satisfactions as the mirror of health care service quality that they received. The important service would become a determinant factor of patients satisfaction is discharge planning service. Discharge planning is activities whichdone by health workers or nurses on preparing patient be able to take action independently after they leave hospital. This research was cross sectional which has purposes to identify index of patient satisfaction on implementing discharge planning by nurses at inpatient rooms class I, II, III, and two hospitals in Jember district with samples 60 respondents who taken by purposive sampling. Questionnaires were used as instrument to collect data. The average of expectation value on first hospital was 3.6690 with average of real value 3.0130.Then, the average of expectation value on second hospital was 3.5510 with average of real value 2.9730. Index of patient satisfaction in first hospital between the expectation and real value there was difference 0.656 and 0.578 on second hospital. The result of $t$ test showed that there was difference on mean of expectation and real value in first hospital ( $p$ value $=0.004 ; \alpha=0.05$ ) and in second hospital ( $p$ value $=0.016 ; \alpha=0.05$ ). Therefore the implementation of discharge planning was still remain to be cultured on health workers themselves, including nurses, so thus implementation was not yet optimum and it have still not give satisfaction for patients as service receiver or customer.
\end{abstract}

Keywords: Discharge Planning, Patients Satisfaction, Inpatients

\section{PENDAHULUAN}

Pelayanan kepada pasien bukan saja difokuskan pada tercukupinya fasilitas maupun sarana prasarananya. Unsur penting yang dapat dijadikan cermin pelayanan yang berkualitas, yaitu terpenuhinya hak pasien mulai dari awal masuk sampai dengan pulang dari rumah sakit. Salah satu hak yang melekat pada diri pasien dan keluarganya saat masuk rumah sakit untuk menjalani perawatan adalah mendapatkan informasi tentang kesehatannya secara komprehensif untuk persiapan menghadapi pemulangan (discharge planning).

Discharge planning merupakan layanan yang harus diberikan kepada setiap pasien rawat inap. Layanan discharge planning merupakan tanggung jawab seluruh tenaga kesehatan yang ada di rumah sakit, termasuk perawat. Holliman \& Dziegielewski (2003) menyatakan layanan keperawatan merupakan bagian penting dalam perencanaan pemulangan. Bowman et al (1998) kedepan perawat harus mampu membangun komunikasi yang baik dengan tim kesehatan lainnya.

$$
\text { Program perencanaan }
$$

pemulangan (discharge planning) pada dasarnya merupakan pemberian pendidikan kesehatan kepada pasien yang meliputi nutrisi, aktifitas/latihan, obat-obatan dan instruksi khusus yaitu tanda dan gejala penyakit pasien (Perry \& Potter, 2005) secara lengkap dan komprehensif. Mengingat arah dalam perawatan kesehatan, kebutuhan akan perencanaan pemulangan yang efektif, efisien, dan komprehensif menjadi sangat penting (Bowman et al, 1998). Dengan demikian sebelum pemulangan, pasien dan keluarga harus mengetahui bagaimana cara memanaj masalah kesehatannya, terutama pada waktu nanti menjalani 
perawatan mandiri di rumah (Bastable, 2002). Sehingga menurut Mullen \& Watts Kelley (2006) pasien dan keluarganya memerlukan sistem perawatan kesehatan yang memungkinkan mereka memenuhi beberapa kebutuhan perawatan secara mandiri.

Perawat sebagai salah satu profesi yang merupakan bagian integral dari pelayanan kesehatan mempunyai peran vital dalam menciptakan pembelajaran yang inovatif guna memberikan pendidikan kesehatan kepada pasien. Pembelajaran kepada pasien yang diberikan mulai pertama kali masuk rumah sakit sampai dengan menjelang pemulangan akan dapat menentukan kemampuan pasien dalam perawatan mandiri selama rawat inap di maupun setelah pulang dari rumah sakit.

Pendidikan kesehatan kepada pasien dan keluarga yang diberikan secara intensif akan dapat memberikan informasi kesehatan yang berdampak terhadap meningkatnya pengetahuan dan keterampilan pasien dan keluarga. Hal ini sangat menentukan kualitas pelayanan yang diberikan secara keseluruhan. Kualitas pelayanan yang baik, secara signifikan akan meningkatkan kepuasan pasien selama menerima pelayanan. Sejauh ini menurut Harrykissoon (2003) konsumen (pasien dan keluarganya) juga menuntut informasi kesehatan yang berarti.

Berbagai macam cara untuk mengukur tingkat kepuasan pasien terhadap pelayanan yang diterima. Sebagai tolok ukur dalam melihat kepuasan pasien adalah dengan membandingkan antara harapan dan kenyataan/kinerja pelayanan yang pasien terima. Jika harapan pasien lebih tinggi, maka akan semakin sulit untuk memenuhinya (Sun \& Burnside, 2010) dan sebaliknya. Harapan pasien yang lebih tinggi bila dibandingkan dengan kenyataan/kinerja dapat diartikan pasien tidak puas (Asmuji, 2014).

\section{METODE PENELITIAN}

Penelitian ini merupakan penelitian cross sectional yang bertujuan mengidentifikasi indeks kepuasan pasien terhadap pelaksanaan discharge planning oleh perawat di ruang rawat inap kelas I, II, dan III dua rumah sakit di Kabupaten Jember dengan sampel sebanyak 60 responden diambil secara purposive sampling. Instrumen pengumpulan data menggunakan kuesioner. Analisis data yang digunakan adalah analisis univariat/deskriptif yang ditampilkan dalam bentuk tabel distribusi frekuensi dan analisis bivariat menggunakan uji statistik t-test dengan $\alpha=0.05$.

\section{HASIL}

Tabel 1 menunjukkan bahwa rata-rata nilai harapan pada rumah sakit I adalah 3,6690 dengan rata-rata nilai kenyataan 3,0130. Rata-rata nilai harapan pada rumah sakit II adalah 3,5510 dengan rata-rata nilai kenyataan 2,9730. Indeks kepuasan pasien di rumah sakit I antara harapan dan kenyataan terdapat selisih 0,656 dan di rumah sakit II selisihnya 0,578. Hasil uji statistik (t-test) menunjukkan adanya perbedaan rata-rata nilai harapan dan kenyataan, baik di rumah sakit I (pvalue $=0,004 ; \alpha .=0,05$ ) maupun di rumah sakit II (pvalue $=0,016 ; \alpha .=$ 0,05). Hasil penelitian dikedua rumah sakit menunjukkan indeks 
kepuasan pasien di rumah sakit I antara harapan dan kenyataan terdapat selisih 0,664 dan di rumah sakit II selisihnya 0,546 .

Table 1. Distribusi Rata-Rata Indeks Kepuasan Pasien terhadap Pelaksanaan Discharge Planning oleh Perawat di Rumah Sakit di Kabupaten Jember.

\begin{tabular}{|c|c|c|c|c|c|c|c|c|c|}
\hline \multirow[b]{2}{*}{ RS } & \multicolumn{2}{|c|}{ Mean } & \multicolumn{2}{|c|}{ Median } & \multicolumn{2}{|c|}{ Modus } & \multicolumn{2}{|c|}{ SD } & \multirow[b]{2}{*}{$\begin{array}{c}P \\
\text { value }\end{array}$} \\
\hline & $\begin{array}{l}\text { Expected } \\
\text { Value } \\
\end{array}$ & $\begin{array}{c}\text { Real } \\
\text { Value }\end{array}$ & $\begin{array}{c}\text { Expected } \\
\text { Value } \\
\end{array}$ & $\begin{array}{c}\text { Real } \\
\text { Value }\end{array}$ & $\begin{array}{c}\text { Expected } \\
\text { Value } \\
\end{array}$ & $\begin{array}{c}\text { Real } \\
\text { Value }\end{array}$ & $\begin{array}{l}\text { Expected } \\
\text { Value }\end{array}$ & $\begin{array}{c}\text { Real } \\
\text { Value }\end{array}$ & \\
\hline I & 3,669 & & & & 4,00 & 4,00 & & 1,036 & 0,00 \\
\hline II & 3,551 & 2,973 & 3,530 & 3,200 & 3,00 & 4,00 & 0,269 & 1,038 & 0,01 \\
\hline
\end{tabular}

\section{PEMBAHASAN}

Kepuasan pasien merupakan komponen penting dari kinerja organisasi di rumah sakit (Adulkader et al, 2013; Koné Péfoyo \& Wodchis, 2013; Mfinanga et al, 2008; Workbook 6, 2013). Kepuasan pasien merupakan konsep yang kompleks (Oliveras et al., 2005), bersifat multidimensi (Kullberg et al, 2017) yang berisi penilaian tentang pelayanan (Beck et al, 1999) kesehatan yang mereka terima. Kepuasan pasien menjadi acuan bagi penyedia layanan kesehatan untuk meningkatkan dan memenuhi kebutuhan pasien, serta meningkatkan efektivitas layanan (Elizabeth et al., 2005) dengan cara meningkatkan perilaku perawat yang berorientasi pada pelanggan (Lim Lee et al, 2014). Sehingga, menurut Bahari (2010) staf pendukung harus terlatih dan diperkaya dengan keterampilan atau pengetahuan khusus untuk menangani pasien.

Salah satu kegiatan penting dalam pelayanan kesehatan adalah mempersiapkan pemulangan pasien. Hochberger (1995) perencanaan pemulangan merupakan bagian integral dari asuhan keperawatan yang harus dimulai sesegera mungkin setelah pasien dirawat di unit rawat inap. Perencanaan perawatan, termasuk rencana pemulangan yang baik dan menurut Tin-Oo \& Saddki (2011) bisa diterima oleh pasien menyebabkan tingkat kepuasan pasien semakin tinggi.

Kepuasan pasien terhadap persiapan pemulangan (discharge planning) merupaka ungkapan yang dirasakan oleh pasien terhadap pelayanan kesehatan yang mereka terima selama menjalani rawat inap. Perasaan puas seorang pasien dapat diukur dengan berbagai instrument. Sudah cukup banyak upaya telah dilakukan untuk mengembangkan instrumen survei untuk mengukur kepuasan pasien (Sofaer \& Firminger, 2005). Salah instrument yang biasa dipergunakan untuk mengukur tingkat kepuasan seorang pasien terhadap pelayanan yang mereka terima adalah dengan membandingkan antara harapan yang mereka inginkan dengan kenyataan yang mereka terima (Sun \& Burnside, 2010). Jika, pelayanan yang mereka terima sesuai dengan harapan yang mereka inginkan, maka dapat dikatakan individu tersebut puas. Jika, pelayanan yang mereka terima lebih jelek daripada harapan yang mereka inginkan, maka dapat dikatakan pasien merasa tidak puas. Sedangkan, jika pelayanan yang mereka terima melebihi harapan yang mereka inginkan, maka dapat 
dikatakan bahwa pasien merasa sangat puas (Asmuji, 2014).

Persiapan pemulangan pasien (discharge planning) bukan hanya sekedar kegiatan yang dilakukan pada waktu pasien akan keluar rumah sakit. Tetapi, merupakan kegiatan merancang pelayanan seputar kebutuhan pasien (Hobson, 2013) yang harus dilakukan sesegera mungkin (Hochberger, 1995) mulai pertama kali masuk rumah sakit - selama menjalani perawatan - dan menjelang keluar rumah sakit. Kegiatan ini harus dilakukan secara berkesinambungan dan konsisten untuk semua pasien. Namun dalam kenyataannya, hak-hak pasien mendapatkan informasi diawal kali masuk rumah sakit sering tidak diberikan dengan semestinya.

Pemberian informasi yang memadai (Mukhopadhyay et al, 2016) dan lengkap kepada pasien beserta keluarganya akan memberikan dampak psikologis berupa ketenangan jiwa. Penjelasan yang baik tentang situasi dan kondisi lingkungan pasien yang dilakukan perawatan akan menambah rasa tenang. Lingkungan baru bagi sebagian orang merupakan stressor. Individu yang menerima stresor akan mempersepsi stresor serta akan merespon stresor sehingga mencapai keseimbangan baru (eustress) atau malah akan menyebabkan terjadinya gangguan keseimbangan (distress) terhadap individu tersebut (Prasetyo, 2006). Adaptasi yang tidak adaptif akan membuat individu bisa jatuh sakit. Stres merupakan respon tubuh yang tidak spesifik terhadap setiap kebutuhan tubuh yang terganggu, suatu fenomena universal yang terjadi dalam kehidupan sehari-hari dan tidak dapat dihindari, setiap orang mengalaminya, stres memberi dampak secara total pada individu yaitu terhadap fisik, psikologis, intelektual, stres dan fisiologis (Rasmun, 2004).

Individu yang sehat secara fisik saja bisa jatuh sakit akibat kegagalan dalam beradaptasinya, apalagi pasien yang secara fisik sudah sakit. Maka, ini akan dapat memperparah penyakitnya, sehingga dapat mempengaruhi kecepatan penyembuhannya. Bahwa gangguan kejiwaan dapat berpengaruh terhadap lamanya kesembuhan penyakit seseorang ataupun kekambuhan suatu penyakit (Kuspriyadi, 2007).

Mengenal lingkungan baru membuat seseorang akan merasa nyaman dan aman secara fisik maupun psikologis. Kenyamanan dan keamanan yang dirasakan seseorang akan mempengaruhi system imun. Sehingga, bila dalam kondisi imun yang menurun, pertahanan tubuh pun akan menurun dan tubuh bisa mudah terserang penyakit kemudian sakit (Waspodo, 2008). Hasil penelitian Mayasari (2009) memperlihatkan hubungan yang signifikan antara stres dengan tingkat kekambuhan. Berdasarkan data dan fakta di atas, maka pengenalan lingkungan baru kepada pasien yang rawat inap sangat dibutuhkan. Mengenal lingkungan baru secara utuh akan membuat seseorang lebih mudah konsentrasi. Dengan demikian pasien akan semakin mudah menerima informasi yang dibutuhkan selama menjalani rawat inap, sehingga akan berdampak pada kemampuannya dalam menolong dirinya sendiri disaat menjalani perawatan selama di rumah. Pernyataan di atas didukung oleh pendapat Wang et al (2015) yang menyatakan bahwa lingkungan 
perawatan memainkan peran penting dalam mewujudkan kualitas pelayanan.

Lingkungan baru akan ditandai dengan tata acara dan adat yang berbeda. Perbedaan tempat juga berkonsekuensi terhadap aturan yang berbeda pula. Sebagai pasien yang masuk pada lingkungan baru, tentu membutuhkan keterangan yang lengkap tentang aturan yang harus dipatuhi. Hal ini untuk mengurangi atau menghindari kesalahan-kesalahan yang dilakukan oleh pasien dan keluarganya. Sehingga pihak rumah sakit harus memfasilitasi kebutuhan pasien yang seperti itu. Kebutuhan akan penjelasan hak dan kewajiban pasien menjadi prioritas. Karena hal ini juga termaktup dalam UU no. 44 tahun 2009 pasal 32 yang disebutkan pasien berhak memperoleh informasi tentang hak dan kewajiban pasien. Pemahaman pasien yang baik berkenaan dengan hak dan kewajibannya selama menjalani rawat inap akan sangat membantu dalam meningkatkan kesembuhan. Contoh riil kewajiban pasien pun harus disebutkan adalah pasien berkewajiban untuk mentaati segala instruksi dokter dan perawat dalam pengobatannya. Dengan demikian pasien akan selalu mengingat apa kewajibannya selama di rumah sakit maupun sewaktu sudah pulang dari rumah sakit.

Kondisi status kesehatan pasien pun wajib disampaikan kepada pasien. Pernyataan ini sangat relevan dengan isi UU no. 44 tahun 2009 pasal 32 yang menyebutkan bahwa pasien berhak mendapatkan informasi yang meliputi diagnosis dan tata cara tindakan medis, alternative tindakan, risiko, dan komplikasi yang mungkin terjadi.
Namun, hasil penelitian ditemukan data bahwa indeks kepuasan pasien terhadap perawat dalam memberikan penjelasan/informasi tentang penyakit/kondisi pasien waktu pertama kali datang walaupun tidak diminta masih jauh dari harapan. Hal ini bertolak belakang dengan tujuan discharge planning yaitu memberikan informasi tentang kondisi kesehatan pasien walaupun tidak diminta.

Memberikan informasi terutama penyediaan informasi oleh perawat (Kullberg et al, 2017) tentang kondisi pasien merupakan kewajiban tenaga kesehatan dalam setiap memberikan pelayanan. Informasi tentang kondisi pasien juga merupakan hak yang harus diterima oleh pasien maupun keluargannya. Selain itu, pasien dan keluarga juga berhak mendapatkan informasi-informasi yang berkenaan dengan segala yang terkait dengan penyakitnya, termasuk penjelasan tentang hasil laboratorium. Karena, menurut Luthy et al. (2017) peningkatan kepuasan pasien kemungkinan disebabkan oleh karena mendapatkan informasi yang cukup tentang kesehatan dan perawatannya.

Pemberian informasi tentang kondisi kesehatan pasien dan hasil pemeriksaan laboratorium merupakan bagian pendidikan kesehatan yang nantinya akan dapat meningkatkan pengetahuan pasien dan keluarganya. Peningkatan pengetahuan pasien dapat memudahkan terjalinnya kolaborasi antara perawat/tenaga kesehatan dengan pasien dalam upaya mengatasi masalah kesehatannya. Luthy et al. (2017) juga menyatakan pemberian informasi secara intens dapat dijadikan kesempatan untuk 
mendiskusikan perawatan yang disesuaikan dengan kebutuhan pasien dan pengambilan keputusan bersama.

\section{SIMPULAN}

Pemberian informasi tentang segala hal yang menyangkut hak dan kewajiban pasien selama menjalani perawatan ditemukan masih belum banyak dilakukan dengan baik. Hal ini dapat dilihat dari hasil pengumpulan data penelitian yang ditemukan indeks kenyataan yang nilainya di bawah 2,00 . Rerata nilai harapan yang lebih tinggi daripada kenyataan dapat dijadikan acuan untuk menyimpulkan bahwa pasien belum merasa puas terhadap pelaksanaan discharge planning di kedua rumah sakit.

\section{DAFTAR PUSTAKA}

Adulkader, N. M., \& Triana, B. E. G. (2013). Physician satisfaction with hospital clinical laboratory services in Aden Governorate, Yemen, 2009. Eastern Mediterranean Health Journal; Alexandria, 19(6), 555-60.

Asmuji. (2014). Manajemen Keperawatan: Konsep \& Aplikasi. (Nurhid, Ed.) (3rd ed.). Jogjakarta: Ar-Ruzz Media.

Bahari, M. B., \& Ling, Y. W. (2010). Factors contributing to customer satisfaction with community pharmacies in Malaysia. Journal of Public Health; Heidelberg, 18(1), 35-41.

Bastable, S. B., Wulandari, G., Widiyanto, G., \& Widyastuti, P. (2002). Perawat sebagai pendidik: prinsip-prinsip pengajaran dan pembelajaran
(Nurse as educator: principles of teaching and learning). Jakarta: EGC.

Beck, E. J., Griffith, R., Fitzpatrick, R., \& Mandalia, S. (1999). Patient satisfaction with HIV service provision in NPMS hospitals: The development of a standard satisfaction questionnaire. AIDS Care; Abingdon, 11(3), 331-43.

Bowman, K. F., Rose, J. H., \& Kresevic, D. (1998). Family Caregiving of Hospitalized Patients. Journal of Gerontological Nursing; Thorofare, 24(8), 8-16.

Harrykisson, D. (2003). The effects of access, communication, and customer service on member satisfaction with health care in a federal managed care plan. Walden University.

Hochberger, J. M. (1995). A Discharge Check List for Psychiatric Patients. Journal of Psychosocial Nursing \& Mental Health Service; Thorofare, 33(12), 35-38.

Holliman, D., Dziegielewski, S. F., \& Teare, R. (2003). Differences and Similarities Between Sosial Work and Nurse Discharge Planners. Health \& Social Work, 28(3), 224.

Koné Péfoyo, A. J., \& Wodchis, W. P. (2013). Organizational performance impacting patient satisfaction in Ontario hospitals: a multilevel analysis. $B M C$ Research Notes; London, 6, 509.

Kullberg, A., Sharp, L., Johansson, H., Brandberg, Y., \& Bergenmar, M. (2017). Patient satisfaction after implementation of person-centred handover in 
oncological inpatient care - A cross-sectional study. PLoS One; San Francisco, 12(4).

Kuspriyadi. (2007). No Title. Retrieved January 12，2018, from www.medscape.com

Luthy, C., Gerstel, P. F., Pugliesi, A., Piguet, V., \& Allaz, A.-F. (2017). Bedside or not bedside: Evaluation of patient satisfaction in intensive medical rehabilitation wards. PLoS One; San Francisco, 12(2).

Mayasari, D., \& Pratiwi, A. (2009).

Hubungan respon imun dan stres dengan tingkat kekambuhan demam tifoid pada masyarakat di Wilayah Puskesmas Colomadu Karanganyar. Jurnal Berita Ilmu Keperawatan, 2(1), 13-18.

Mfinangga, S. G. et al. (2008). Patient's dissatisfaction with the public and private laboratory services in conducting HIV related testing in Tanzania. BMC Health Services Research, 8, 167-171.

Mukhopadhyay, A., Song, G., Sim, P. Z., Kit, C. T., \& Jeffrey, K. S. Y. (2016). Satisfaction domains differ between the patient and their family in adult intensive care units. BioMed Research International; New York.

Muninjaya, A. A. G. (2011). Manajemen mutu pelayanan kesehatan. (J. Suyono \& L. Indra, Eds.). Jakarta: EGC.

Oliveras, E., Larsen, U., \& David, P. H. (2005). Client satisfaction with abortion care in three Russian Cities. Journal of Biosocial Science; Cambridge, 37(5), 585-601.

Perry, A. G., \& Potter, P. A. (2006). Clinical nursing skills \& tecnique (6th ed.). Missouri: Mosby Inc.

Ping, L. L., \& Ahmad, U. N. U. (2015). A Conceptual Analysis of Nurses' Customer-Oriented Behavior, Job Satisfaction and Affective Commitment in Malaysia. International Journal of Caring Sciences; Nicosia, 8(3), 774-782.

Prasetyo, D. H. (2006). Psikoneuroimunologi untuk keperawatan (2nd ed.). Surakarta: UNS Press.

Rasmun. (2004). Stres, koping, dan adaptasi. Jakarta: Agung Seto.

Sofaer, S., \& Firminger, K. (2005). Patient perceptions of the quality of health service. Annual Review of Public Health; Palo Alto, 26, 513-59.

Sun, N., Burnside, G., \& Harris, R. (2010). Patient satisfaction with care by dental therapists. British Dental Journal ; London, E9(discussion), 212-3.

Tin-Oo, M. M., Saddki, N., \& Hassan, N. (2011). Factors influencing patient satisfaction with dental appearance and treatments they desire to improve aesthetics. BMC Oral Health; London, 11, 6.

Wang, Y., Dong, W., Mauk, K., Li, P., \& Wan, J. (2015). Nurses' Practice Environment and Their Job Satisfaction: A Study on Nurses Caring for Older Adults in Shanghai. PLoS One; San Francisco, 10(9).

Waspodo. (n.d.). All about stress. Retrieved January 12, 2018, from www.allaboutstress.com

WHO. (2000). Client satisfaction evaluations (Workbook 6). Geneva: WHO. 